
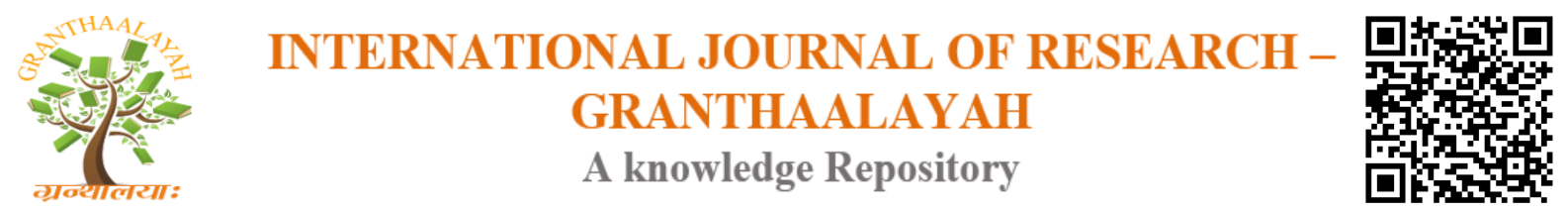

Science

\title{
SANITARY RISK FACTORS AND MICROBIAL PROFILE IDENTIFICATION BY MALDI-TOF OF STREET READY-TO-EAT MEAT PRODUCTS CONTAMINANTS
}

\author{
Paul Attien ${ }^{1,2,3}$, Thomas Dadie ${ }^{2}$, Haziz Sina ${ }^{* 3}$, Clément Kouassi Kouassi ${ }^{1}$, Lamine Baba- \\ Moussa $^{3}$ \\ ${ }^{1}$ Laboratory of Biochemistry and Microbiology, UFR Agroforestry of the University Jean \\ Lorougnon Guédé. BP 150 Daloa, Ivory Coast \\ ${ }^{2}$ Laboratory of Biotechnology and Food Microbiology, Faculty of Food Science and \\ Technology; University Nangui Abrogoua. BP 801 Abidjan 02, Côte d'Ivoire \\ ${ }^{3}$ Laboratory of Biology and Molecular Typing in Microbiology, Faculty of Sciences and \\ Techniques, University of Abomey-Calavi, 05 BP 1604 Cotonou, Benin
}

\begin{abstract}
Many persons use to eat ready-to-eat meat products sold mostly on the street. The aim of our study was to investigate the microbial contaminants profile of meat products sold on the streets of 5 communes in Abidjan. To reach our goal, a survey was conducted to investigate on the type of customer, meat, the selling points, and the probable causes of food poisoning. Forty samples of each of the three kind of ready-to-eat meat (beef, pork and chicken) were collected in five communes of Abidjan. The microbial quality of the collected meat was determined with conventional methods and confirmed by matrix-assisted laser desorption ionization-time-offlight mass spectrometry. The results of the survey showed a health risk potentially related to the method of cooking and the type of meat. Out of the 600 samples analyzed, 443 strains were isolated. Among the microorganisms, there are Cocci's (61.61\%) mainly Staphylococcus strains, Bacilli (37.28\%) and yeast (1.11\%). Staphylococcal strains and Enterobacteriaceae are the most predominant and chicken meat is the most contaminated meat product. Also, some strains (Alloiococcus otitis and Ochrobactrum intermedium) were rarely isolated. The meat products contamination constitutes a health risk which could cause significant income loss for both merchant and consumer.
\end{abstract}

Keywords: Food Safety; Meat Product; Health Risks Factors; MALDI TOF MS; Abidjan.

Cite This Article: Paul Attien, Thomas Dadie, Haziz Sina, Clément Kouassi Kouassi, and Lamine Baba-Moussa. (2017). "SANITARY RISK FACTORS AND MICROBIAL PROFILE IDENTIFICATION BY MALDI-TOF OF STREET READY-TO-EAT MEAT PRODUCTS CONTAMINANTS." International Journal of Research - Granthaalayah, 5(12), 164-175. https://doi.org/10.29121/granthaalayah.v5.i12.2017.490. 


\section{Introduction}

Food safety remains a global concern despite the many efforts made by health and sanitation organizations [1]. Foodborne infections are reported worldwide and it was estimates to be involved in more than 2 million deaths per year, mainly children [2], due solely to food and water inadequate sanitation and hygiene. Food contamination remains a real and permanent risk, especially in cities where this risk is closely linked to the consumption of ready to eat street foods [3-4]. Across the world and specifically in Africa, several countries have experienced episodes of food poisoning without scientifically proofed of given food involvement.

Indeed, it is currently observe an anarchic creation of occasionally sale point mainly on the principal or secondary roads near gutters, crossroads, markets, bus stations, etc. Among the street food sold on such environment, embers meat or cooked in sauce occupies an important place. Indeed, meat products are an important source mineral such as iron, zinc, magnesium and selenium and also contain considerable concentrations of phosphorus and potassium, which are important for human health [5]. Peoples around the selling site are potential customer for street meat product traders [6]. Ingredients used for the confection of the street food are of diverse origins including as well as legal sources and illegal ones [7]. Thus, several studies have shown that street food use raw materials and ingredients of poor microbiological quality because nonauthorized person are involved in the sector of activity [8-11]. Street foods generate employment opportunities, especially for low- or uneducated individuals [12-13]. The income obtained is mainly used for the renewal of stocks and for certain expenditures at the household level [12]. Foodborne infections are linked to the ingestion of street meat containing bacteria and / or toxins. Foods often contaminated include dairy products and meat [14]. They are characterized by the presence of painful abdominal cramps, diarrhea, vomiting and absence of fever. All these symptoms occur 1 to 6 hours after the ingestion of infected foods. The germs involved in food poisonings are numerous and the most frequent are Salmonella, Escherichia coli and Staphylococcus aureus [15]. Ingestion of bacteria or toxins may cause the digestive tract to dysfunction in the body of the consumer [16]. Symptoms usually manifest in severe vomiting, diarrhea and abdominal pain in humans. This contamination is also responsible for death in young animals in livestock [17-18]. The bacteria involved in community food poisonings are frequently isolated from the manufacturer's processing, transport and sales environment [12, 1920]. It should be noted that preventive treatment is generally neglected in favor of healing [21]. There is lack of reported scientific data on the prevalence, diversity, resistance and toxinotypy of Staphylococcus strains, particularly in the food sector in Côte d'Ivoire. Thus, the aim of this study was to draw the microbial contaminants profile of meat products sold on the streets of 5 communes in Abidjan.

\section{Materials and Methods}

\subsection{Study Area}

Samples of meats sold in Cote d'Ivoire were collected in the study area for microbial analysis. The ready-to-eat meat samples used for this study were collected from sales sites (in the vicinity 
of public catering establishments, markets, dwellings, schools and bus stations) of five municipalities (Abobo, Yopougon, Adjamé, Treichville and Port-Bouet) in Abidjan (Figure 1).

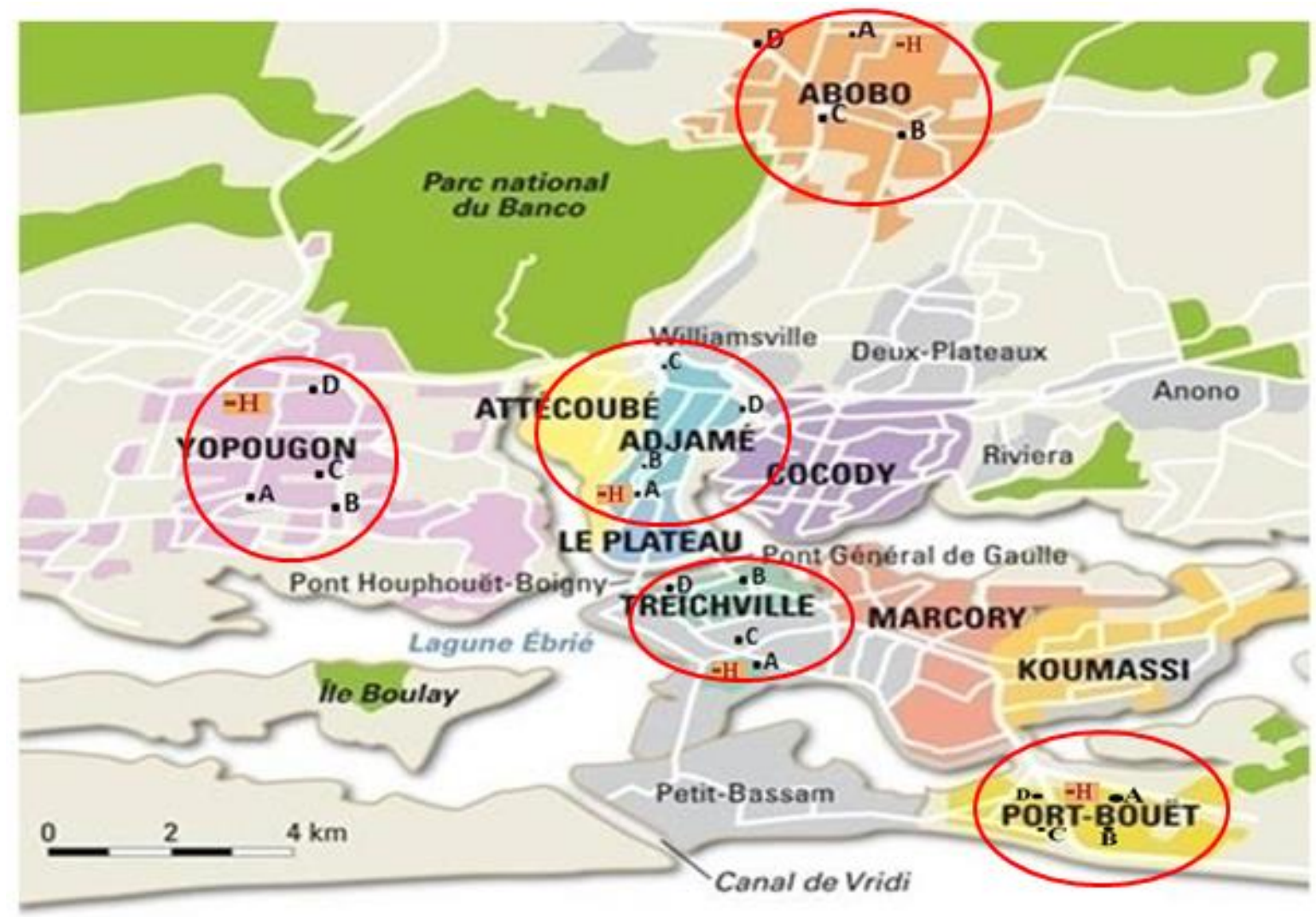

Figure 1: Ready-to-eat meat sample collection area

Sampling sites selected for each commune: A (habitats), B (public buildings or schools), C (market) and D (bus station), H (Hospital).

Sampling communes

\subsection{Sample Size and Data Collection}

\section{Sample size and kind of meat product}

The sample size is calculated according to the following formula: $\mathbf{n}=\mathbf{p}(\mathbf{1 - p}) /[\mathbf{e} / \mathbf{1 . 9 6}]^{\mathbf{2}}$ (with $\mathbf{n}$ $=$ minimum sample size required; $\mathrm{p}=$ estimation of the expected proportion (prevalence); $\mathrm{e}=$ tolerated margin of error (\%) estimated here at 5\%) [22].

Three kind of ready-to-eat meat (beef, pork and chicken) sold in cooked form in sauce or braised on a rack were collected for their microbial analysis (Figure 2). Per commune, four (A, B, C and D) different samples collection point were selected to collect 40 samples of each of the three meat kind. Thus, a total of 120 samples were collected in each of the five investigated communes. Once collected, the meat samples were transported within the hour following the collection in ice container $\left(4-8^{\circ} \mathrm{C}\right)$ for immediate microbial analysis in the laboratory. 


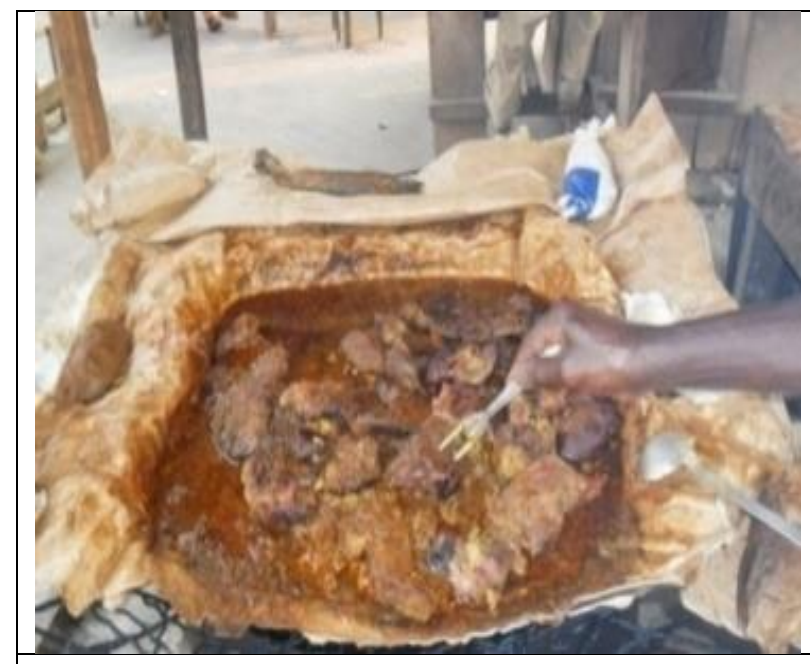

A. Beef meat

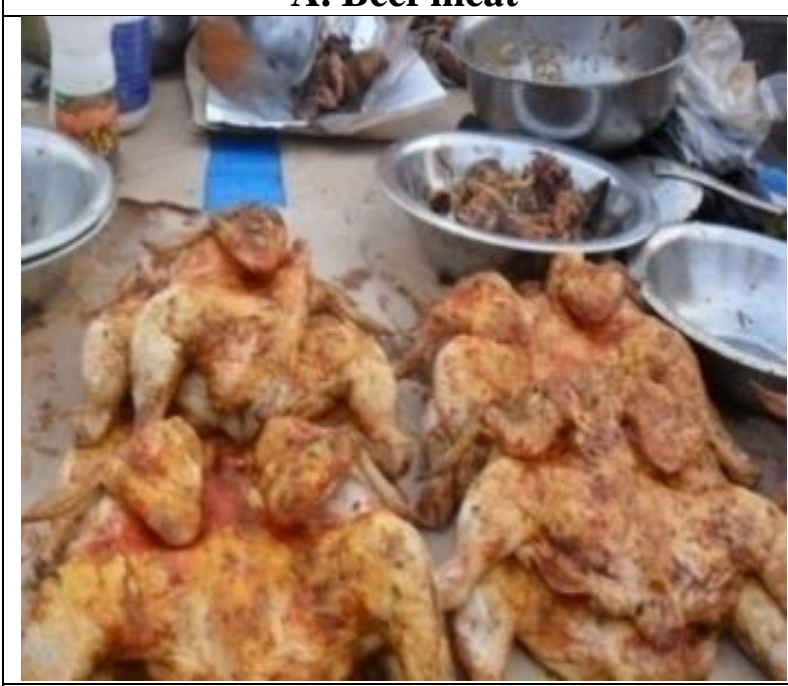

C. Chicken meat

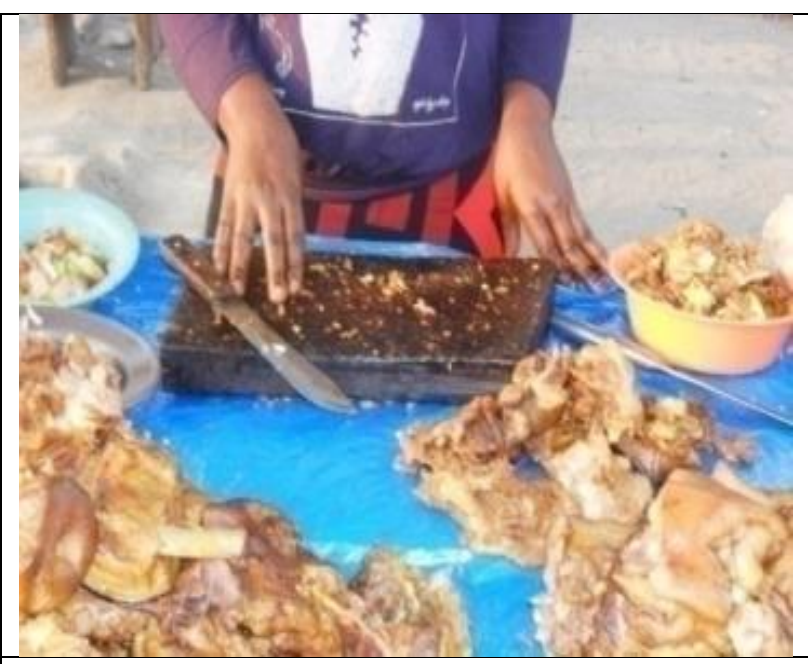

B. Pork meat

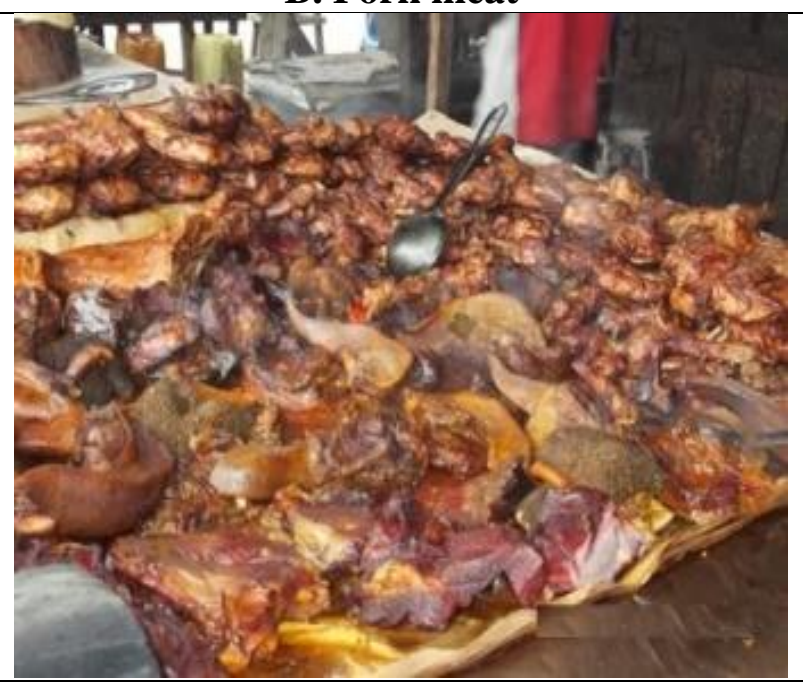

D. Mixed cooking of chicken, beef and mutton

Figure 2: Picture showing the kind of meat collected

\section{Investigation}

A survey was carried out using the "snowball" survey technique [23-24]. It consists in having other surrounding sales sites indicated from a reference point to the original site [25]. The survey took into account the type of customer, the type of meat, the safety-related point of sale and probable cases borne outbreaks associated and other parameters such as the consumer age, type of meat, and form of cooking, consumption place and packaging type.

\subsection{Microbial Analysis}

For the microbiological analysis, $25 \mathrm{~g}$ of each meat sample was added to $225 \mathrm{~mL}$ of brain heart broth in stomacher sachets (CM0941, Oxoid, Germany). After adding 0.01\% potassium tellurite (SR0030, Oxoid), the mixture was homogenized aseptically [19]. For the enrichment, the sachet 
and its contents was incubated at $37^{\circ} \mathrm{C}$ for 1 to 3 hours. From the incubated suspension, a decimal dilution was made with peptone water (BioRad, Paris, France). Each dilution (0.1 ml) was spread on Baird Parker agar (Biokar Diagnostics, France) with egg yolk [26-27] before it incubation at $37^{\circ} \mathrm{C}$ for 48 hours for gram positive coccis. For Enterobacteriaceae, Hektoen agar and EMB agar (Biokar Diagnostics, France) were used to seed the inoculum and incubated at $37^{\circ} \mathrm{C}$ for 24 hours. To end, Sabouraud Chloramphenicol agar (Biokar Diagnostics, France) was used for yeasts.

Once isolated, the microorganisms were isolated using classical morphological (gram staining, shape of bacteria, and Ziehl-Neelsen staining) and biochemical characters (sugar fermentation, Oxidase, Methyl red-Voges-Proskauer, indole and Catalase test) related to the genus identification techniques [28-29] (Janda and Abbott, 2002; Cowan and Steel, 2003). The identification was then confirmed by matrix-assisted laser desorption ionization-time-of-flight mass spectrometry (MALDI TOF/ MS) as previously described [30]. Briefly, from the previous culture, a colony was removed and co-crystallized with a (3,5-dimethoxy-4-hydroxycinnamic acid [sinapinic acid] and $\alpha$-cyano-4-hydroxycinnamic acid (CHCA) matrix on a steel plate. This strain-matrix complex is then bombarded by a laser beam emitting in the absorption zone of the matrix. The ions thus generated in the ionization chamber are accelerated in an electric field which directs them to an analyzer. The analyzer separates and classifies the accelerated ions according to their free flight time (emission speed) according to the mass-to-load (m/z) ratio allowing the smallest molecules to arrive first to the detector. Molecules that have very close $\mathrm{m} / \mathrm{z}$ ratios can be separated within a certain limit by an electrostatic mirror [30]. A detection and identification phase which consisted of a detector to receive and transform the ions into electrical current which is amplified and digitized. The interpretation is carried out using a recognition algorithm which considers the positions of the peaks whose intensity is included in a scale of 1 to 1000 [31-33]. The MALDI software automatically generates a list of peaks from the spectrum obtained after unknown sample analysis (Biotyper System, Bruker Daltonics TM). This list of peaks is then compared to peak lists stored in a MALDI database for the bacterial identifications.

After the isolation and identification of the strains, the frequency of contamination was calculated from the ratio of contaminated products on all the products. The prevalence was obtained by the ratio of the strains isolated on all the biological products tested.

\subsection{Data Analysis}

The results of the survey were analyzed with the SPSS 19 (SPSS Inc., Chicago, USA). Descriptive statistics such as prevalence, mean and standard deviation were calculated for the quantitative variables. A significant difference between the mean was determined. The relative risk (RR) of disease reported after consumption of meat was calculated for various hypothetical risk factors. The mean probability of ready-to-eat meat contaminated at the level posing a risk to human health was calculated as the proportion of meat multiplied by the proportion of sold meat. The main parameter used were the age of the consumer, the type of meat, the form of cooking, the place of consumption, the packaging type. The threshold of statistical significance was set at $\mathrm{p}<0.05$. 


\section{Results and Discussions}

\subsection{Results}

\section{Microbial Quality of the Ready-To-Eat Meat}

The table 1 shows that a total of 443 strains were isolated including gram positive cocci's (276), gram negative bacilli (146), gram positive bacilli (16) and yeasts (5). The prevalence of contaminants is higher in the communes of Port-Bouet (131), Abobo (119) and Adjamé (89).

Table 1: Prevalence of isolated germs in street meats according to commune

\begin{tabular}{|c|c|c|c|c|c|c|c|}
\hline COMMUNE & SAMPLES & $\begin{array}{c}\text { Gram+ } \\
\text { Cocci }\end{array}$ & $\begin{array}{l}\text { Gram - } \\
\text { Bacillus }\end{array}$ & $\begin{array}{l}\text { Gram + } \\
\text { Bacillus }\end{array}$ & Yeast & Total & $\begin{array}{l}\text { Rate } \\
(\%)\end{array}$ \\
\hline$A B O B O$ & 120 & 70 & 41 & 7 & 01 & 119 & 27 \\
\hline ADJAME & 120 & 56 & 30 & 3 & & 89 & 20 \\
\hline YOPOUGON & 120 & 38 & 25 & & & 63 & 14 \\
\hline TREICHVILLE & 120 & 29 & 12 & & & 41 & 09 \\
\hline \multirow[t]{2}{*}{ PORT-BOUET } & 120 & 83 & 38 & 5 & 04 & 131 & 29 \\
\hline & 600 & 276 & 146 & 16 & 05 & 443 & \\
\hline
\end{tabular}

The use of MALDI TOF reveal 11 different species of Staphylococci with a predominance of $S$. sciuri (32.8\%). The chicken meat contained the large number of Staphylococci (128 strains). Also, Alloiococcus otitis strains were found in chicken samples collected and analyzed (Table 2).

Table 2: Prevalence of cocci species and subspecies identified by MALDI TOF

\begin{tabular}{|c|c|c|c|c|c|c|}
\hline Spices & Sub spices & Beef & Pork & Chi & Total & Rate (\%) \\
\hline Staphylococcus & & & & & & \\
\hline & S. aureus ATCC & 11 & 5 & 8 & 24 & 54 \\
\hline S. aureus & S. aureus ssp aureus & 16 & 4 & 10 & 30 & 54 \\
\hline S sciuni & S. sciuri $\operatorname{ssp}$ sciuri & 23 & 14 & 31 & 68 & 00 \\
\hline S. sciuri & S. sciuri $\mathrm{ssp}$ carnaticus & 8 & 5 & 9 & 22 & 90 \\
\hline S. simulans & S. simulans DSM & 9 & 12 & 19 & 40 & 40 \\
\hline & S. xylosus DSM & 6 & 9 & 17 & 32 & \\
\hline S. xylosus & S. xylosus FIFLR & 0 & 0 & 0 & $\mathbf{0}$ & 32 \\
\hline & S. cohnii ssp cohnii & 0 & 0 & 6 & 6 & \\
\hline S. connil & S. cohnii ssp urealyticus & 0 & 3 & 5 & 8 & 14 \\
\hline S. lentus & S. lentus DSM & 0 & 5 & 7 & 12 & \\
\hline & S. haemolyticus $M B$ & 4 & 0 & 0 & 4 & \\
\hline S. haemolyticus & S. haemolyticus ESL & 6 & 0 & 0 & 6 & 10 \\
\hline S. saprophyticus & S. saprophyticus ssp saprophyticus & 54 & 2 & 2 & 8 & \\
\hline S. capitis & S. capitis ssp capitis & 2 & 0 & 4 & 6 & \\
\hline S. succinus & S. succinus ssp succinus & 0 & 0 & 6 & 6 & \\
\hline S. equorum & S. equorum ssp equorum & 0 & 0 & 2 & 2 & \\
\hline
\end{tabular}




\begin{tabular}{llllll}
\hline Alloiococcus otitis DSM 7252T DSM & 0 & 0 & 2 & $\mathbf{2}$ \\
\hline Total & $\mathbf{8 9}$ & $\mathbf{5 9}$ & $\mathbf{1 2 8}$ & $\mathbf{2 7 6}$ \\
\hline
\end{tabular}

Among the Bacillus, a large number of Enterobacteriaceae with a predominance of Enterobacter cloacae (29), Escherichia coli (27) and Proteus mirabilis (25) were identified (Table 3). Apart of the above mentioned strains, Ochrobactrum intermedium, Bacillus cereus and Candida sorbosa strain were also identified.

Table 3: Prevalence of species and subspecies of bacilli and yeasts identified by MALDI TOF

\begin{tabular}{|c|c|c|c|c|c|c|}
\hline \multirow{2}{*}{$\begin{array}{l}\text { Spices } \\
\text { Enterobacteriaceae }\end{array}$} & \multirow[t]{2}{*}{ Sub spices } & \multicolumn{2}{|c|}{ Beef Pork } & \multicolumn{3}{|c|}{ Chicken Total $\begin{array}{l}\text { Rate } \\
(\%)\end{array}$} \\
\hline & & & & & & \\
\hline \multirow{3}{*}{ Escherichia coli } & ATCC 25922 THL & 6 & 0 & 10 & 16 & 27 \\
\hline & DH5alpha BRL & 0 & 0 & 5 & 5 & \\
\hline & MB11464_1 CHB & 2 & & 4 & 6 & \\
\hline \multirow{3}{*}{ Enterobacter cloacae } & MB_5277_05 THL & 0 & 5 & 13 & 18 & 29 \\
\hline & MB̄11506_1 CHB & 0 & 2 & 7 & 9 & \\
\hline & 13159_1 CHB & 0 & & 2 & 2 & \\
\hline \multirow{3}{*}{ Klebsiella pneumoniae } & ssp ozaenae CCM 5792 CCM & 5 & 0 & 3 & 8 & 25 \\
\hline & ssp ozaenae DSM $16358 T$ HAM & 2 & 0 & 4 & 6 & \\
\hline & ssp pneumoniae 9295_1 CHB & 2 & 0 & 9 & 11 & \\
\hline \multirow{2}{*}{ Proteus mirabilis } & $9482 \_2 C H B$ & 8 & 0 & 0 & 8 & \\
\hline & $(P X) 22086112 M L D$ & 6 & 0 & 0 & 6 & \\
\hline Citrobacter koseri & 9553_1 CHB & 0 & 7 & 0 & 7 & \\
\hline \multicolumn{7}{|l|}{ Other Bacillus Gram - } \\
\hline $\begin{array}{l}\text { Pseudomonas } \\
\text { pertucinogena }\end{array}$ & $L M G 1874 T$ HAM & 1 & 11 & 6 & 18 & \\
\hline $\begin{array}{l}\text { Acinetobacter } \\
\text { haemolyticus }\end{array}$ & LMG 1033 HAM & 0 & 0 & 5 & 5 & \\
\hline Acinetobacter & 13101_1CHB & 2 & 0 & 11 & 13 & 21 \\
\hline baumannii & $L M G 994 H A M$ & 2 & 0 & 7 & 8 & \\
\hline $\begin{array}{l}\text { Ochrobactrum } \\
\text { intermedium }\end{array}$ & LMG $3301 T$ HAM & 0 & 0 & 1 & 1 & \\
\hline \multicolumn{7}{|l|}{ Bacillus Gram + } \\
\hline \multirow[t]{2}{*}{ Bacillus cereus } & $4080 \mathrm{LBK}$ & 1 & 0 & 8 & 9 & 15 \\
\hline & $994000168 \mathrm{LBK}$ & 0 & 0 & 6 & 6 & \\
\hline \multicolumn{7}{|l|}{ Yeast } \\
\hline Candida sorbosa [ana] & $\begin{array}{ll}\text { (Issatchenkia } & \text { occidentalis } \\
\text { [teleo]\#) CBS } 1910 & \\
\end{array}$ & 0 & 0 & 5 & 5 & \\
\hline Total & & 37 & 25 & 105 & 167 & \\
\hline
\end{tabular}

\section{Heath Risk Factors}

The health risk survey reveals several types of information depending on the investigated parameter (Table 4). The vendor's ages mainly vary from 19 to over 50 years. Thus, the active 
population is exposed to the risk of food-borne illness. After streets meat consumption, the risks of infection occurred varying from 1.04 to 1.10. Also, the highest intoxication risks were recorded through the consumption of goat meat (OR: 2.25) and beef (OR: 1.04). The cooking process is also one of the determining factors linked to the food poisoning risks. Except the meat cooked on a grid or steak, all the other forms of cooking displays high (from 1.12 to 1.54) contamination risk. In addition a supplement contamination factor is the selling place. Thus, our data showed that the places with highest contamination rate are those close to schools and public buildings (2.98). However, the rate of contamination at bus station remains the most significant $(\mathrm{p}<0.05)$.

Table 4: Risk related to the age of the consumer, the type of meat, the form of cooking, the place of consumption, the packaging type associated with the infection

\begin{tabular}{|c|c|c|c|c|c|c|}
\hline \multirow{2}{*}{\multicolumn{2}{|c|}{$\begin{array}{l}\text { Potential Risk Factor } \\
\text { Category }\end{array}$}} & \multirow{3}{*}{$\begin{array}{c}\% \\
\text { Consummation } \\
3.3 \\
\end{array}$} & \multirow{3}{*}{$\begin{array}{c}\begin{array}{c}\text { Univariate OR } \\
\text { (95\% IC) }\end{array} \\
0.35(0.39-3.25) \\
\end{array}$} & \multirow{2}{*}{$\begin{array}{c}\text { R-1/R fraction } \\
\text { etiologic expose } \\
(95 \% \text { IC) }\end{array}$} & \multirow[t]{2}{*}{$\mathbf{P}$} & \multirow{2}{*}{$\begin{array}{c}\text { V of } \\
\text { Cramer }\end{array}$} \\
\hline & & & & & & \\
\hline \multirow{4}{*}{$\begin{array}{l}\text { Consumers } \\
\text { age }\end{array}$} & $2(15-18)$ & & & & 0.32 & 0.339 \\
\hline & $3(19-25)$ & 19.3 & $1.04(0.45-2.36)$ & 0.038 & 0.55 & 0.931 \\
\hline & $4(26-49)$ & 69.3 & $1.10(0.54-2.23)$ & 0.090 & 0.47 & 0.799 \\
\hline & $5(>50)$ & 8.1 & $1.05(0.32-3.46)$ & 0.047 & 0.58 & 0.941 \\
\hline \multirow[t]{5}{*}{ Type of meat } & Beef & 70.0 & $1.04(0.51-2.12)$ & 0.038 & 0.53 & 0.913 \\
\hline & Chicken & 62.7 & $0.97(0.50-1.91)$ & & 0.54 & 0.938 \\
\hline & Pork & 42.7 & $0.89(0.46-1.72)$ & & 0.43 & 0.730 \\
\hline & Kid & 3.3 & $\begin{array}{ll}2.25 & (0.36- \\
13.88) & \end{array}$ & 0.555 & 0.33 & 0.371 \\
\hline & Sheep & 16.7 & $0.97(0.40-2.32)$ & & 0.56 & 0.941 \\
\hline \multirow{6}{*}{$\begin{array}{l}\text { Cooking } \\
\text { Form }\end{array}$} & Wire rack & 67.3 & $0.87(0.44-1.75)$ & & 0.42 & 0.704 \\
\hline & Sauce & 67.3 & $1.12(0.56-2.26)$ & 0.107 & 0.44 & 0.743 \\
\hline & Fried & 18.0 & $1.15(0.52-2.80)$ & 0.130 & 0.40 & 0.659 \\
\hline & Oven & 24.7 & $1.15(0.54-2.44)$ & 0.130 & 0.43 & 0.713 \\
\hline & Pike & 12.0 & $1.54(0.57-4.13)$ & 0.350 & 0.27 & 0.390 \\
\hline & Steak & 8.7 & $0.89(0.28-2.87)$ & & 0.55 & 0.849 \\
\hline \multirow{4}{*}{$\begin{array}{l}\text { Consumption } \\
\text { places }\end{array}$} & Home & 4.0 & $0.72(0.13-4.06)$ & & 0.42 & 0.709 \\
\hline & School & 43.3 & $2.98(1.51-5.86)$ & 0.664 & 0.01 & 0.001 \\
\hline & Markets & 32.7 & $0.78(0.39-1.58)$ & & 0,42 & 0.495 \\
\hline & $\begin{array}{l}\text { Bus } \\
\text { stations }\end{array}$ & 20.0 & $0.87(0.15-0.93)$ & & 0.02 & 0.031 \\
\hline \multirow[t]{4}{*}{ Package type. } & $\begin{array}{l}\text { Cement } \\
\text { package }\end{array}$ & 51.3 & $0.55(0.28-1.07)$ & & 0.55 & 0.077 \\
\hline & Newspaper & 16.7 & $0.96(0.40-2.32)$ & & 0.56 & 0.941 \\
\hline & $\begin{array}{l}\text { Attieke } \\
\text { leaves }\end{array}$ & 2.7 & $1.47(0.20-10.76)$ & 0.319 & 0.53 & 0.700 \\
\hline & $\begin{array}{l}\text { Aluminum } \\
\text { foil }\end{array}$ & 16.0 & $1.57(0.65-3.78)$ & 0.363 & 0.21 & 0.310 \\
\hline
\end{tabular}

RR (Relative risk); FEPe (etiological fraction in exposed population); PAF (fraction of attributable risk in population) FEPe and PAF calculate only for risk cases. 


\subsection{Discussion}

The study shows that meat sold on the street has many hygiene problems. In particular, meat products such as beef, chicken and pork have been contaminated by numerous germs such as staphylococci and enterobacteria. The level of contamination of these meat products varies from a kind of meat product to another. Thus, the prevalence of Staphylococcus strains in meat products is $62 \%$ with $28 \%$ in chicken and $20 \%$ in beef. Among the isolated bacteria, the predominant strains were Staphylococcus aureus, S. sciuri, Escherichia coli, Enterobacter cloaca and Klebsiella pneumoniae, on chicken meat $(52.60 \%)$ and beef $(28.22 \%)$. The predominance of contaminants in chicken meat may be explained by the fact that this meat is sold with its skin, which is the most contaminated part of the consumed meat [34-35], while beef (particularly the analyzed portions) is generally separated from the skin. Thus, it appear that meat are good thank of Staphylococcus strains. In the same, several studies reported the varieties and high contamination rates (10-72\%) of Staphylococcus strains isolated from meat [36-39]. Fang et al. [35] found that Staphylococcus was found to be $88 \%$ stable in beef sandwiches in Thailand. In addition, Shale et al. [39] identified Staphylococcus species as contaminants of beef meat during slaughter. However, our results are different from those reported by Barro et al. [15] who founded that fecal peril germs as major contaminants of street foods with a predominance of Escherichia coli. Our results suggest that the consumption of beef and goat meat sold as ready to eat are at risk focusing to the large number of food-borne outbreaks cases with respective risks of 1.04 and 2.25. The prevalence of contaminants in these meat products varies according to the commune with the highest rate of contamination of products from Port-Bouet (29\%) followed by Abobo (27\%), Adjame (20\%), Yopougon (14\%) and finally Treichville (9\%). The presence of contaminants in meat (from 10 to $72 \%$ ) products has been demonstrated to varying degrees, [37, 38, 39] and sausage [40-42]. The prevalence of Staphylococcus and Escherichia coli isolated in meat products sold in Abidjan is similar to the one obtained on traditional beer made from dried beef (Kilishi) in Cameroon by Fonkem et al. [43]. In Cameroon, a variation in contamination rate was observed from a district to another but the infection risks are not linked to the communes. Thus, the reported risks are linked to sales sites near schools and public buildings. However, the rate of infection at bus station level remains significant $(\mathrm{p}<0.05)$. The high level of meat contamination from commercial buildings, public buildings and railway stations could be explained by the high number of passengers, customers and traders at these sites. In such sites, the atmosphere heavily overburdened with smoke and dust, the multiplication of all kinds of garbage, the proximity of sellers with the pipes which are generally open pit and added to this, the lack of hygiene of the sellers. These sites are the preferred selling points for fixed, semistationary and mobile vendors because of the large number of people visiting these places. The high contamination of meat may be due to food handling. Indeed, several unhygienic behaviors such as the use of hands, packaging of old newspaper sheets, and the absence of an appropriate device for cleaning utensils during its high levels of contamination. Similar observations have been reported in Burkina Faso [15] and in Benin [44] in their studies on the quality of street foods. In addition, the exposure of this meat to the microflora of actors involved in transport, processing and sale would be one of the main sources of contamination. The state of disrepair in marketing and preservation channels added to unhygienic behavior could also be one of the causes of high contamination level. It is therefore very important, for the consumer, to be sur that the ready-to-eat meat are well prepared. Also, it is better to buy and consume such food when they are hot. One of the best way to carry the product once bought remain the use of clean 
implement such as aluminum foil and single use dishes. The sellers are invited to have better hygienic behavior.

\section{Conclusions}

This work shows that meat sold on the street of Abidjan are ready to eat are highly contaminated by microorganism such as Staphylococcus ssp. and Enterobacteriaceae. These germs are for most of them involved in food poisoning. However their presence does not justify the occurrence of food poisoning. In addition, there is a lack of hygienic behavior among the persons involve in the production of this food. All the risk factors contribute to a health risk for consumers depending on the place of sale, the type of meat, the type of packaging and many other factors related to the lack of hygiene. Brown \& Jennings (1989) in the article on "Outperformance of Technical analysis" showed that technical analysis has value in a model in which prices are not fully revealing and traders have rational speculation about the relation between prices and signals.

\section{References}

[1] Ackah M, Gyamfi ET, Anim AK, Osei J, Hansen JK, Agyemang O. Socio-Economic Profile, Knowledge Of Hygiene And Food Safety Practices Among Street-Food Vendors In Some Parts Of Accra-Ghana. J. Food Safety. 2011; 13: 191-197.

[2] World Health Organization, 2015. Initiative to Estimate the Global Burden of Foodborne Diseases. Available from: http://www.who.int/foodsafety/foodborne_disease/ferg/en/index.html

[3] Tambekar D, Jaiswal V, Dhanorkar D, Gulhane P, Dudhane M. Identification Of Microbiological Hazards And Safety Of Ready-To-Eat Food Vended Streets Of Amravati City, India. J. Appl. Biosci. 2008; 7: 195-201.

[4] Akhtar S, Sarker MR, Hossain A. Microbiological Food Safety: A Dilemma of Developing Societies. Crit. Rev. Microbiol. 2012; 40(4): 348-359.

[5] Olmedilla-Alonso B, Jiménez-Colmenero F, Sánchez-Muniz FJ. Development And Assessment Of Healthy Properties Of Meat And Meat Products Designed As Functional Foods. Meat Sci. 2013; 95(4): 919-30.

[6] Dawson RJ, Canet C. International Activities in Street Foods. Food Control. 1991; 2:135-139.

[7] Bryan FL, Michanie S, Fernández MN, Vizcarra MM, Taboada PD, Navarro SO, Alonso AB, Requejo GE. Hazard Analyses of Foods Prepared by Migrants Living In a New Settlement at the Outskirts of Lima, Peru. J. Food Prot. 1988; 51(4): 314-323.

[8] Bereda TW, Emerie YM, Reta MA, Asfaw HS. Microbiological Safety Of Street Vended Foods In Jigjiga City, Eastern Ethiopia. Ethiop. J. Health Sci. 2016; 26(2): 161-170.

[9] Klontz K, Timbo B, Fein S, Levy A. Prevalence of Selected Food Consumption and Preparation Behaviors Associated With Increased Risks of Food-Borne Disease. J. Food Prot. 1995; 58(8): 927-930.

[10] Idowu O, Rowland S. Oral Fecal Parasites and Personal Hygiene of Food Handlers in Abeokuta, Nigeria. Afr. Health Sci. 2006; 6(3): 160-164.

[11] Rane S. Street Vended Food in Developing World: Hazard Analyses. Ind. J. Microbiol. 2011; 51(1), 100-106.

[12] Barro N, Nikiéma P, Ouattara CAT, Traoré AS. Evaluation De L'hygiène Et De La Qualité Microbiologique De Quelques Aliments Rue Et Les Caractéristiques Des Consommateurs Dans Les Villes De Ouagadougou Et De Bobo-Dioulasso (Burkina Faso). Rev. High Pressure Sci. Technol. 2002; 25: 7-21. 
[13] Khairuzzaman M, Chowdhury FM, Zaman S, Al Mamun A, Bari ML. Food Safety Challenges towards Safe, Healthy, and Nutritious Street Foods in Bangladesh. Int. J. Food Sci. 2014, ID. 483519.

[14] Zinzendorf NY, Baba-Moussa L, Yao C, Bouhoua LG, Sanni A, Loukou YG. Prévalence De Staphylococcus Aureus Enterotoxinogène Dans Le «Dégué» Vendu Dans Trois Communes De La Ville d'Abidjan, Côte d'Ivoire. Microbiol. Hyg. Alim. 2009; 21(62): 41-44.

[15] Barro N, Aly S, Tidiane OC, Sababenedjo TA. Carriage Of Bacteria By Proboscises, Legs, And Feces Of Two Species Of Flies In Street Food Vending Sites In Ouagadougou, Burkina Faso. J. Food Prot. 2006; 69 (8): 2007-2010.

[16] Baba-Moussa L, Ahissou H, Azokpota P, Assogba B, Atindéhou M, Anagonou S, Keller D, Sanni A, Prévost G. Toxins And Adhesion Factors Associated With Staphylococcus Aureus Strains Isolated From Diarrheal Patients In Benin. Afr. J. Biotechnol. 2010; 9(5): 604-611.

[17] Zschöck M, Sommerhauer J, Castaneda H. Relatedness Of Staphylococcus Aureus Isolates From Bovine Mammary Gland Suffering From Mastitis In Single Herd. J. Dairy Res. 2000; 67(3): 429435.

[18] [18]. Barber DA, Miller GY, McNamara PE. Models Of Antimicrobial Resistance And Foodborne Illness: Examining Assumptions And Practical Applications. J. Food Prot. 2003; 66 (4): 700-709.

[19] Atanassova V, Meindl A, Ring C. Prevalence Of Staphylococcus Aureus And Staphylococcal Enterotoxins In Rawpork And Uncooked Smoked Ham A Comparison Of Classical Culturing Detection And RFLP-PCR. Int. J. Food Microbiol. 2001; 68(1-2): 105-113.

[20] Haeghebaert S, Le Querrec F, Bouvet AP, Gallay E, Vaillant V. Les Toxi-Infections Alimentaires Collectives En France En 2001. BEH. 2002 ; 50: 249-254.

[21] Johnston L, Jaykus L. Antimicrobial Resistance Of Enterococcus Species Isolated From Produce. Appl. Environ. Microbiol. 2004; 70 (5): 3133-3137.

[22] Kadam P, Bhalerao S. Sample Size Calculation. Int. J. Ayurveda Res. 2010; 1(1): 55-57.

[23] Heckathorn DD. Snowball versus Respondent-Driven Sampling. Sociol. Methodol. 2011; 41(1): 355-366.

[24] Atkinson R, Flint J. Accessing Hidden and Hard-To-Reach Populations: Snowball Research Strategies. Social Research Update 2001; 33(1), 1-4.

[25] Sillence E, Briggs P, Harris P, Fishwick L. A Framework For Understanding Trust Factors In Web-Based Health Advice. Int. J. Hum-Comput. Stud. 2006; 64(8): 697-713.

[26] Baird-Parker A. The Staphylococci: an introduction. Soc Applied Bacteriol. Symp Ser. 1990; 19: $1 \mathrm{~s}-8 \mathrm{~s}$.

[27] Akoachere J-FTK, Bughe RN, Oben BO, Ndip LM, Ndip RN. Phenotypic Characterization of Human Pathogenic Bacteria In Fish From The Coastal Waters Of South West Cameroon: Public Health Implications. Rev. Environ. Health. 2009; 24 (2): 147-156.

[28] Janda JM, Abbott SL. Bacterial Identification for Publication: When Is Enough Enough? J. Clin. Microbiol. 2002; 40(6): 1887-1891.

[29] Cowan ST, Steel KJ. Cowan and Steel's manual for the identification of Medical Bacteria. Cambridge University press. 2003

[30] Mellmann A, Bimet F, Bizet C, Borovskaya AD, Drake RR, Eigner U, Fahr AM, He Y, Ilina EN, Kostrzewa M, Maier T, Mancinelli L, Moussaoui W, Prevost G, Putignani L, Seachord CL, Tang YW, Harmsen D. High Interlaboratory Reproducibility Of Matrix-Assisted Laser Desorption Ionization-Time Of Flight Mass Spectrometry-Based Species Identification Of Non-Fermenting Bacteria. J. Clin. Microbiol. 2009; 47(11): 3732-3734.

[31] Dalle F, Lucchi G, Caillot D, Charles PE, Ducoroy P, Bonnin A. Application Des Nouvelles Techniques Microbiologiques Dans L'investigation Et La Prévention Des Infections Associées Aux Soins. PL-08 - Maldi-Tof : Applications Pratiques Aux Champignons. XXIe Congrès National de la SFHH - 2, 3 et 4 juin 2010. 
[32] Moussaoui L. Applications of MALDI-TOF Mass Spectrometry to the Bacteriology and to the Distinction between Genetics Variants. Agricultural Sciences, Université de Strasbourg, French. 2012; < NNT: 2012STRASJ124 >. https // tel.archives-ouvertes.fr/ tel-00872251.

[33] Prod'hom G, Bizzini A, Durussel C, Bille J, Greub G. Matrix-Assisted Laser Desorption Ionization-Time Of Flight Mass Spectrometry For Direct Bacterial Identification From Positive Blood Culture Pellets. J. Clin. Microbiol. 2010; 48(4): 1481-1483.

[34] Jiménez-Colmenero F, Carballo J, Cofrades S. Healthier Meat and Meat Products: Their Role as Functional Foods. Meat Science. 2001; 59(1): 5-13.

[35] Fang J, Fowler P, Tomkinson J, Hill CAS. The Preparation and Physical Characterization of Modified Soybean Polysaccharides. J. Sci. Food Agr. 2002; 82(13): 1523-1527

[36] [36]. De Boer E, Zwartkruis-Nahuis JTM, Wit B, Huijsdens XW, De Neeling AJ, Bosch T, van Oosterom RA, Vila A, Heuvelink AE. Prevalence of Methicillin-Resistant Staphylococcus aureus in Meat. Int. J. Food Microbiol. 2009; 134(1): 52-56.

[37] Olsson C, Ahrné S, Pettersson B, Molin G. The Bacterial Flora Of Fresh And Chill-Stored Pork: Analysis By Cloning And Sequencing Of 16S rRNA Genes. Int. J. Food Microbiol. 2003; 83(3) : 245-252.

[38] Cocolin L, Rantsiou K, Iacumin L, Urso R, Cantoni C, Comi G. Study Of The Ecology Of Fresh Sausages And Characterization Of Populations Of Lactic Acid Bacteria By Molecular Methods. Appl. Environ. Microbiol. 2004; 70(4), 1883-1894.

[39] Shale K, Lues JFR, Venter P, Buys EM. The Distribution of Staphylococcus Sp. on Bovine Meat from Abattoir Deboning Rooms. Food Microbiol. 2005; 22(5): 433-438.

[40] Aymerich T, Martin B, Garriga M, Hugas M. Microbial Quality And Direct PCR Identification Of Lactic Acid Bacteria And Nonpathogenic Staphylococci From Artisanal Low-Acid Sausages. Appl. Environ. Microbiol. 2003; 69(8): 4583-4594.

[41] Rantsiou K, Urso R, Iacumin L, Cantoni C, Cattaneo P, Comi G, Cocolin L. Culture-Dependent And-Independent Methods To Investigate The Microbial Ecology Of Italian Fermented Sausages. Appl. Environ. Microbiol. 2005a; 71(4): 1977-1986.

[42] Rantsiou K, Iacumin L, Cantoni C, Comi G, Cocolin L. Ecology And Characterization By Molecular Methods Of Staphylococcus Species Isolated From Fresh Sausages. Int. J. Food Microbiol. 2005b; 97(3): 277-284.

[43] Fonkem DN, Tanya VN, Ebangi AL. Effects of Season on the Microbiological Quality of Kilishi, a Traditional Cameroonian Dried Beef Product. Tropicult. 2010; 28: 10-15.

[44] Sina H, Baba-Moussa F, Kayodé AP, Noumavo PA, Sezan A, Hounhouigan JD, Kotchoni SO, Prévost G, Baba-Moussa L. Characterization Of Staphylococcus Aureus Isolated From Street Foods: Toxin Profile And Prevalence Of Antibiotic Resistance. J. Appl. Biosci. 2011; 46: 31333143.

*Corresponding author.

E-mail address: sina_haziz@ yahoo.fr 